\title{
Glycol chitosan incorporated retinoic acid chlorochalcone (RACC) nanoparticles in the treatment of Osteosarcoma
}

\author{
Yan-Guo Qin ${ }^{1 *}$, Lan-Yu Zhu ${ }^{2}$, Chen-Yu Wang ${ }^{3}$, Bo-Yan Zhang ${ }^{3}$, Qing-Yu Wang ${ }^{1}$, Rui-Yan Li ${ }^{1}$ and then
}

\section{Abstract}

Background: Osteosarcoma is the most common of all the bone malignancies an a rounts $/ 30-80 \%$ of the primary skeletal sarcomas. The overall survival rate of patients with osteosarcoma is $\$ 20$ ygesting poor prognosis.

Methods: The present study demonstrates the effect of retinoic acid chloroch alco (RACC) incorporated glycol chitosan (GC) nanoparticle transfection in osteosarcoma cells. MG-63 and SaO coma cells were transfected with various concentrations of RACC-incorporated GC nanoparticle for $24 \mathrm{~h}$. The "ect on cell proliferation, Ezh2 expression, apoptosis, cell cycle arrest, cell migration and invasiveness, $A$ osphorylation and local tumour growth and metastases were studied.

Results: MG-63 and Saos-2 osteosarcoma cells on RACC-incornorated GC anoparticle transfection for $24 \mathrm{~h}$ showed a concentration-dependent inhibition of cell proliferation. Of he va us concentrations of RACC tested, the effective concentration started from $5 \mu \mathrm{M}$ with an $\mathrm{IC}_{50}$ of $20 \mu \mathrm{M}$ Wo hec $\mathrm{ng}$ assay also showed that RACC-incorporated GC nanoparticles inhibited migration of tumor cells more effectiven, ompared to the parent RA. RACC transfection resulted in inhibition of cell proliferation, Ezh2 expro inh" biton, apoptosis through mitochondrial pathway by decrease in membrane potential and release of cytoch, ne $/$ and cell cycle arrest in the G0/G1 phase. The invasiveness of cells treated with 5 and $20 \mu \mathrm{M}$ RACC war a vased bs, 49 and $76 \%$ respectively, compared to the control. RACC-treated mice showed significantly wer nu. her of metastases compared to that in the control mice.

Conclusions: Thus, RACC-incorporate d glycol chitosan nanoparticle strategy can be promising for the treatment of osteosarcoma.

Keywords: Osteosarcoma, Mel hrane potential, Migration, Inhibition, Glycol chitosan

\section{Background}

Osteosarcoma is the non of all the bone malignancies and a counts $30-80 \%$ of the primary skeletal sarcoma ( 1 , It frequently attacks the children, teenagers, and your. diults between 10-30 years of age [3]. Cor var'd to females osteosarcoma is more predominantly $\mathrm{O}$ rved in males. The long cylindrical bones like nur, a, and humerus including the knee joint t 1 min target in osteosarcomas [4]. However, the sho ter blade, pelvic, and skull bones are also sometimes affect, d [5]. Osteosarcoma is a well-defined clinical entity

\footnotetext{
* Correspondence: qinyanguo0987@gmail.com

'Department of Orthopedics, The Second Hospital of Jilin University,

Changchun, Jilin 130041, China

Full list of author information is available at the end of the article
}

with a characteristic radiographic appearance, histologic features, a relatively consistent spectrum of clinical presentations, and established standard treatments. These features have been the subject of many prior book chapters and reviews [6-11]. However, all of the present treatments are less efficient. Therefore, the discovery of molecules with roles in the osteosarcoma inhibition is highly desired to improve the clinical treatment.

Polycomb group of genes (PcG) which play a crucial role epigenetically in regulating gene transcription programs possess a catalytic subunit, Enhancer of Zeste homolog 2 (Ezh2) [12]. It has been demonstrated that Ezh2 controls expansion and differentiation of tumor initiating cells and the development and progression of cancer [13-15]. In Myelodysplastic syndromes Ezh2 
functions as a tumor suppressor [16, 17]. It inhibits cell differentiation to maintain stemness of tumor cells $[18,19]$.

Retinoic acids (RAs) have been used in the prevention and treatment of dermatological diseases [20, 21]. Recently retinoic acid and other retinoids have been reported to possess promising anti-cancer activity [22]. It was demonstrated that retinoic acids affect in vitro proliferation, differentiation, and apoptosis of colon [23], prostate [24], lung [25], and leukemia [26] cancers. Moreover, retinoc acids also influence the morphological differentiation, proliferation, and gene expression of neuroblastoma [27] and astrocytoma cells [28]. Recurrent malignant cerebral gliomas have been treated with ATRA $[29,30]$ and 13-cis RA [31]. Despite of its in vitro biological promise, its poor bioavailability under in vivo restricts its clinical applications [32]. One of the techniques to overcome this drawback is the development of polymeric micelles [33], like glycol chitosan micelle. Taking cue from the above literature we devised an experiment to study the effect of RACC (Fig. 1) having more bioavailability compared to the parent compound on human glioma.

\section{Results}

RACC-incorporated GC nanoparticles cause proliferation inhibition in human osteosarcoma cells

The results from MTT assay revealed a dose-aepenc t inhibition of the MG-63 and Saos-2 cell pros vation o, RACC treatment after $24 \mathrm{~h}$. Among the lange concentrations from 1 to $20 \mu \mathrm{M}$ tested, the inhibitio,, 1 was significant at $5 \mu \mathrm{M}$ with a reductio in O.D values of $16 \pm 0.6$ and $13 \pm 0.8 \%$ for MG-63 a Saos 2 cell lines respectively. The reduction in values at 10,15 and
$20 \mu \mathrm{M}$ was $23 \pm 2,63 \pm 3.5,90 \pm 10 \%$ for MG- 63 and 36 $\pm 3.2,64 \pm 3.43$ and $89 \pm 10.34$ for Saos- 2 cells respectively. The $\mathrm{IC}_{50}$ values of RACC were $18.2 \pm 2.8 \mu \mathrm{M}$ for both the tested cell lines.

The daily MTT assay using $20 \mu \mathrm{M}$ RACC for 4 days showed that growth inhibition for both the cell lin was maximum at day 4 (Fig. 2a,c). The trypan blue xclysion assay showed drop in cell number in a time-de a aent manner (Fig. 2b,d).

\section{RACC-incorporated GC nanoparticle trarrsfec ir.nibits}

\section{Ezh2 expression in human osteosa coma cells )}

We used Western blot and RT-P analy is to examine the changes in Ezh2 and p ein levels in MG-63 and Saos-2 cels on CC-incorporated GC nanoparticle treatmer $t$. results showed a significant decrease in Ezh2 expressio level after $24 \mathrm{~h}$ of RACCincorporated $C C$ noparticles $(20 \mu \mathrm{M})$ transfection compared to he Ezh2 inhibition by RACC lasted for at least $h$ after the RACC-incorporated GC nanoparti mansfection (Fig. 3). These results suggest that after be ty, nsfection of the RACC at $20 \mu \mathrm{M}$ for $24 \mathrm{~h}$, the E h2 2 and protein expression levels are effective. nhibited.

- $C$ incorporated GC nanoparticles induce apoptosis in MG-63 and Saos-2 human osteosarcoma cells

We used flow-cytometric and ssDNA detection assay to examine apoptotic cell death in osteosarcoma cells. In MG-63 cells treatment with 5 and $20 \mu \mathrm{M}$ RACC induced apoptosis in $5.89 \pm 3.9$ and $60.54 \pm 5.4 \%$ cells respectively compared to $2.05 \pm 1.01 \%$ cells in control (Fig. 4). Similar results were observed in Saos-2 cells, where in exposure to 5 and $20 \mu \mathrm{M}$ RACC induced

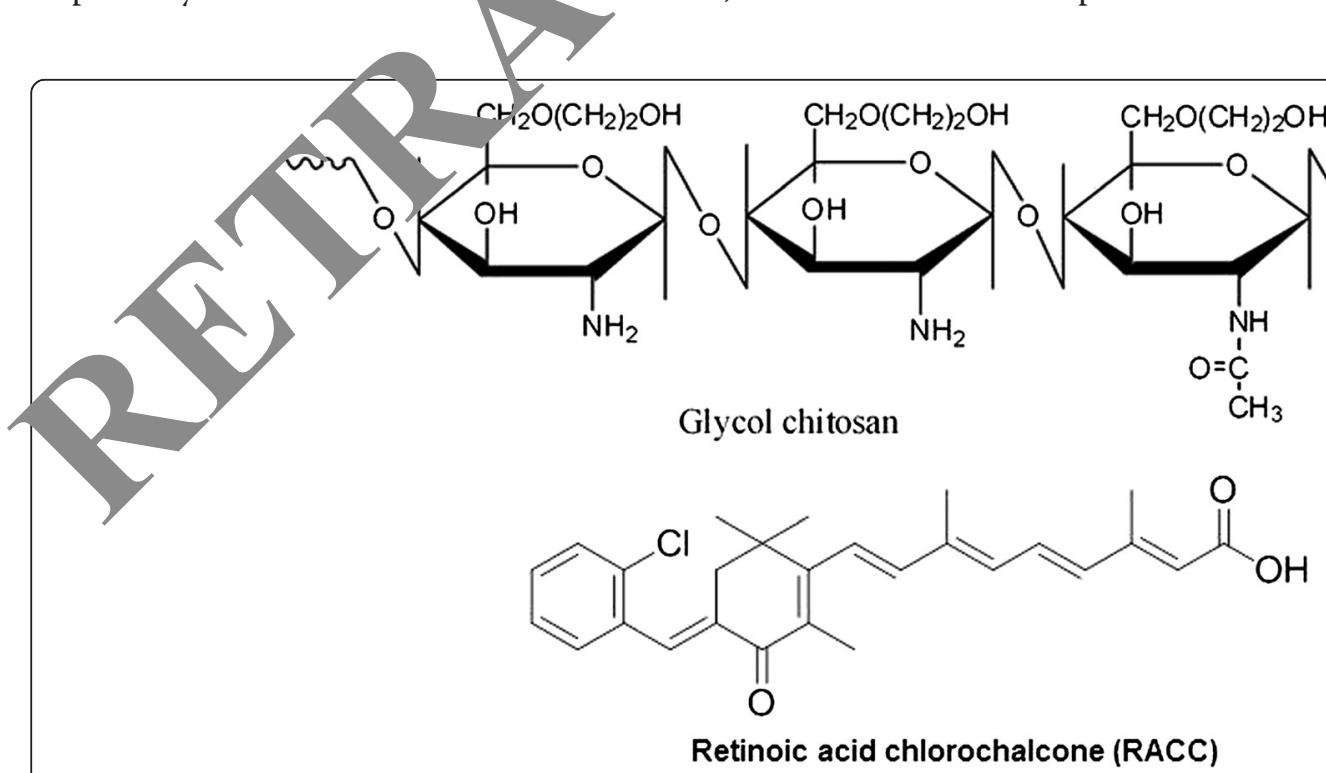

Fig. 1 Structure of retinoic acid chlorochalcone (RACC) and glycol chitosan (GC) 


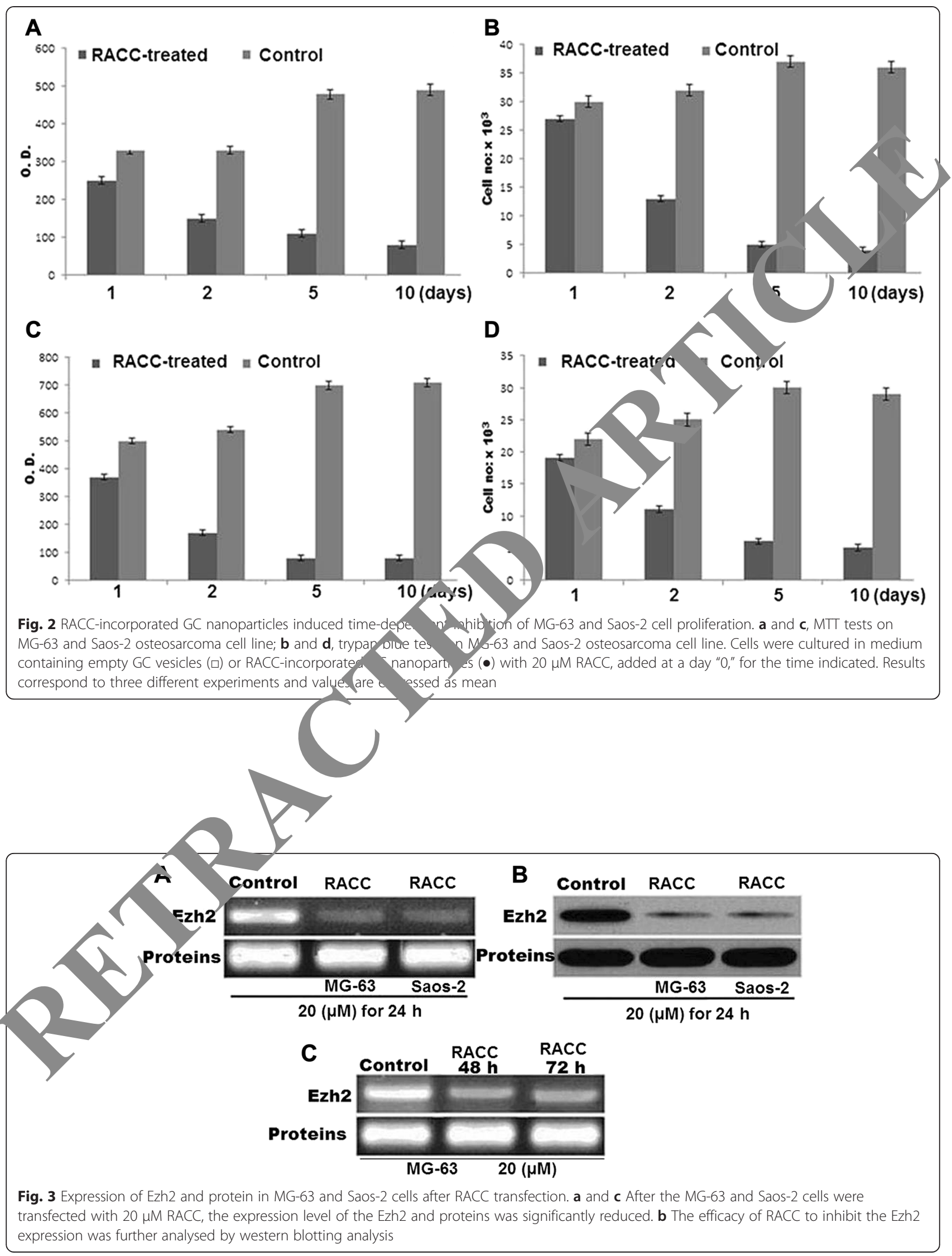



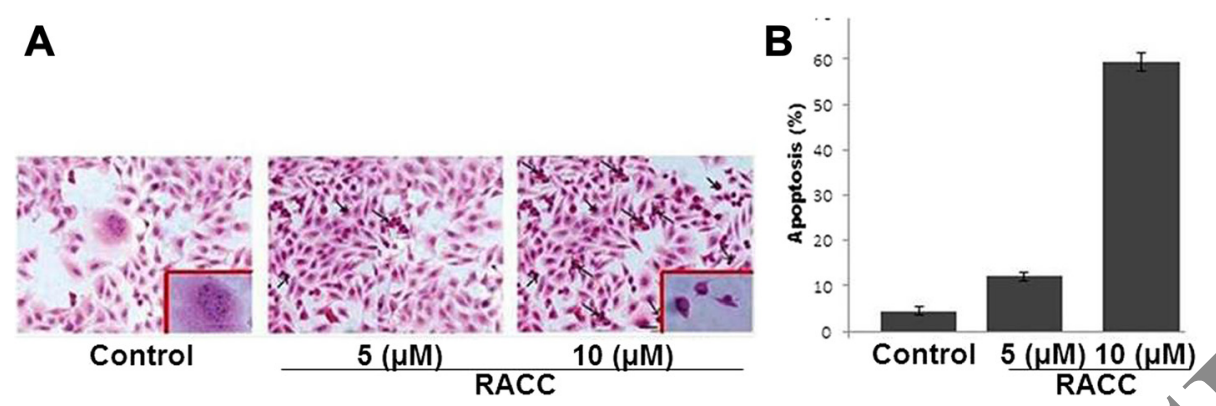

Fig. 4 RACC-induced apoptosis in MG-63 cells. Cultures were grown either in medium containing empty GC vesicles containing $5 \mu \mathrm{M}$ or $20 \mu \mathrm{M}$ RACC. The arrows indicate apoptotic cells; magnified image of cells was shown in corner

apoptosis in $9.86 \% \pm 8.89$ and $47.54 \pm 14.5$ cells respectively compared to $1.79 \pm 0.23 \%$ in control cells (data not shown).

\section{RACC treatment induces apoptosis in the MG-63 and} Saos-2 human osteosarcoma cells through the mitochondrial pathway

We used JC-1 staining to detect the changes in mitochondrial membrane potential in MG-63 and Saos-2 cell lines. The results clearly showed that increase in concentration of RACC in RACC-incorporated GC nanoparticle from $10 \mu \mathrm{M}$ to $25 \mu \mathrm{M}$ significantly reduced the mitochondrial membrane potential in MG-63 cells (Fig. 5a). Western blot analysis revealed transloca $\eta$ ) $f$ Bax and Bcl-2 proteins from mitochondria to oencyt (Fig. 5b). Similar results were obtained in $\mathrm{Sa}_{2}$ huma, osteosarcoma cell lines.

RACC-incorporated GC nanoparticle tı nsfection causes a cell cycle arrest in the G0/G1 phase in -63 . nd Saos-2 human osteosarcoma cells

The results from flow cytometry sbon a significant increase in G0/G1 cell po latio in both MG-63 and Saos-2 cells with sy qu decrease in $S$ and G2/M phase on treatment with RA (5 Fig. 6). The increase in concentration of RAC from $5 \mu \mathrm{M}$ to $20 \mu \mathrm{M}$ led to further increas h percentage of cells in G0/ G1 phase and subsequen sorease in cell percentage from $S$ and G2 M , lase (Fig. 6). These results confirm that RACC tr arrests cell cycle in G0/G1 phase in human o. osarcoma cell lines.

\section{RACC-incorporat, d GC nanoparticle transfection inhibits} cell migratio $n$ and invasiveness

Tr nent with RACC $(20 \mu \mathrm{M})$ for 24 h significantly dereas the migratory activity of MG-63 and Saos-2 cells b. 52 and $58 \%$ respectively compared to control cells (Fig. 7a). The migratory activity of the cells treated with $5 \mu \mathrm{M}$ RACC was decreased by 10 and $40 \%$ respectively in MG-63 and Saos- 2 cells. In invasion assay, the capacity of the RACC-treated MG-63 cells to pass though the Matrigel-coated filters was significantly lower compared to control cells (Fig. 7b). The invasiveness of cells treated with 5 and $20 \mu \mathrm{M}$ RACC was decreased by $49 \%$ and $76 \%(\mathrm{P}<0.001)$, respectively, compared to the control. Knockdown of Has1 and/or Has3 with siRNA revealed that the single knockdown of Has1 or Has3 did not compensate for the effects of RACC on cell motility
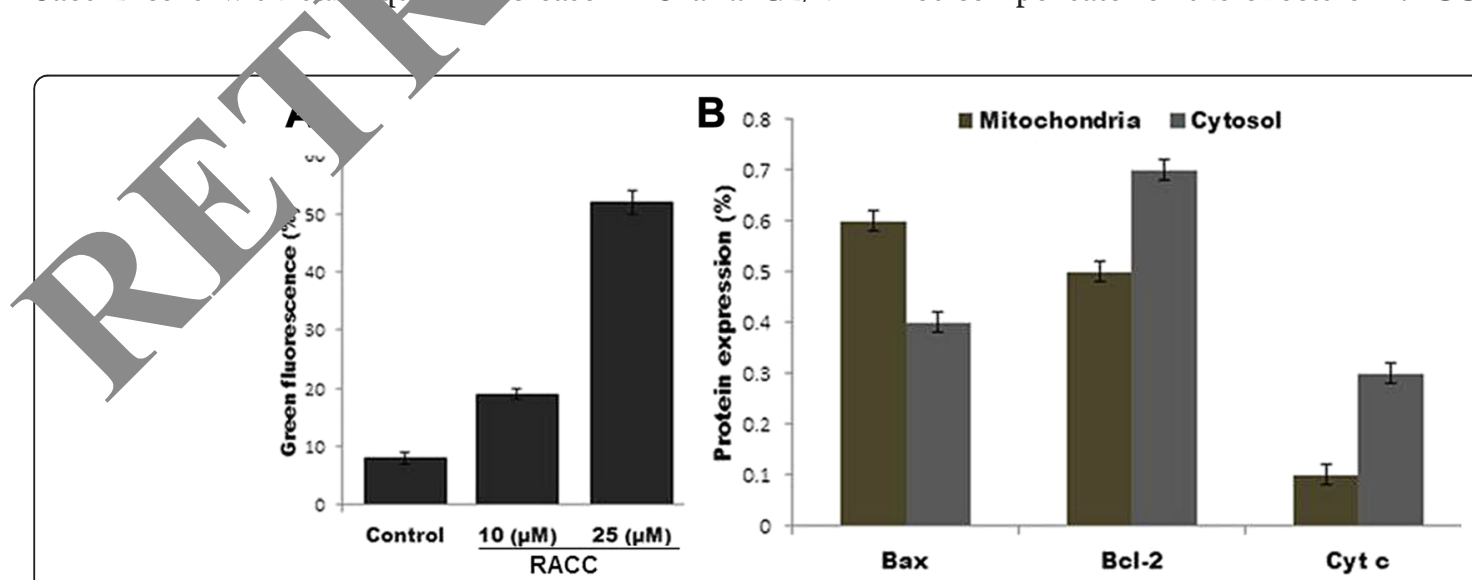

Fig. 5 RACC induces apoptosis in MG-63 cells through the mitochondrial pathway. a Changes in the mitochondrial membrane potential were analysed by JC-1 staining and subsequent flow cytometry. b The expression levels of Bax, Bcl-2, and cytochrome c in the cytoplasm and mitochondria were analysed by western blotting 


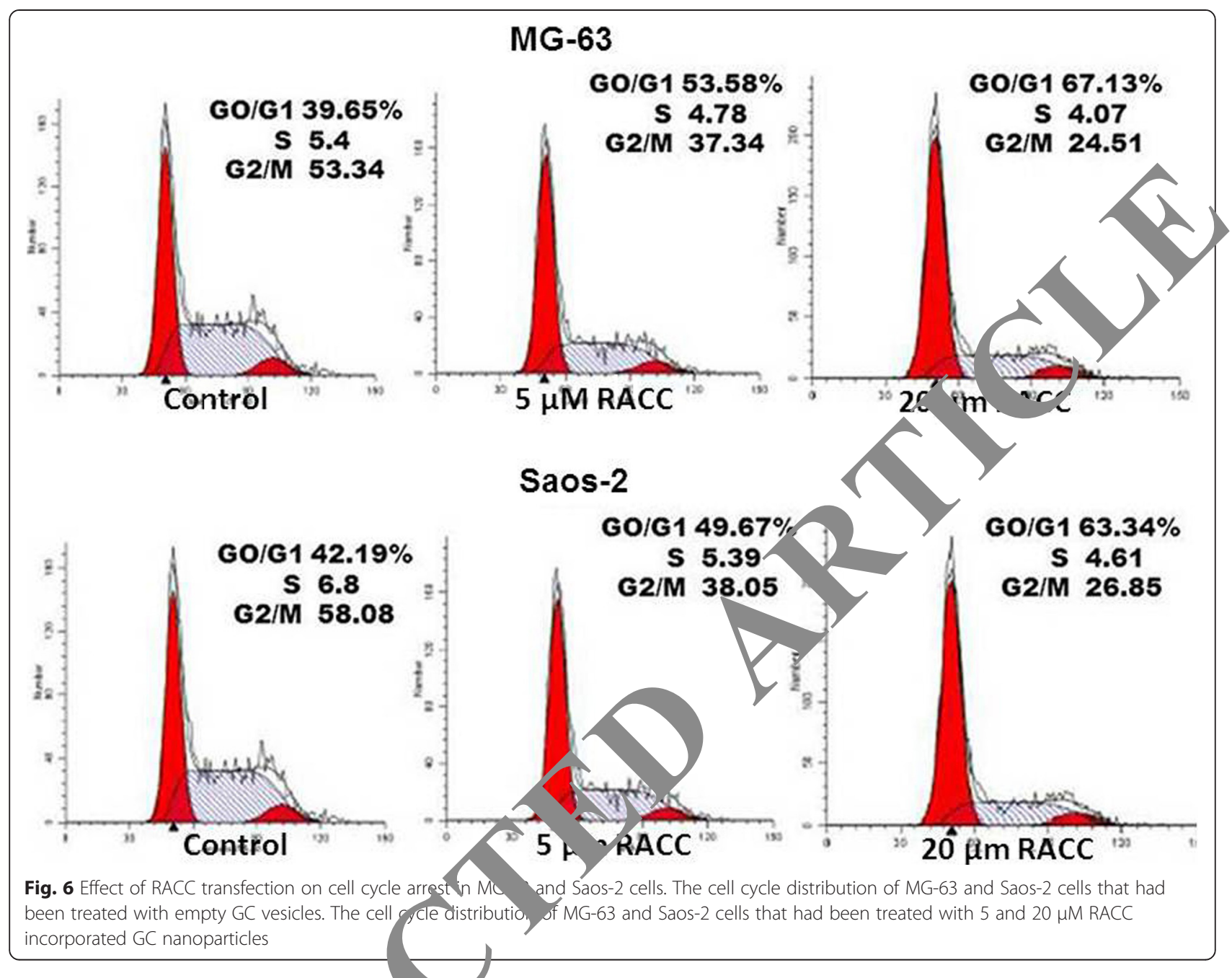

or invasiveness, however the de le knockdown of Has1 and Has3 did (Fig. 7c). Thus surges o the involvement of HA-dependent roy $n$ the inhibitory effects of RACC on cell motilis, nd ariyeness.

RACC-incorpor $/ \mathrm{GC}$ nan particle transfection inhibits Akt phosphorylatio.

We also xamined th- effect of RACC treatment on Akt phospho 7 .an MG-63 and Saos-2 cells using western ot an sione The results revealed a significant deeas in Akt phosphorylation after 5 and $10 \mathrm{~h}$ of RACC th merr than that in the control cells. However, no differen was observed at 1 or $2 \mathrm{~h}$ (Fig. 7d).

RACC-incorporated GC nanoparticle transfection exhibits inhibitory effects on local tumour growth and metastases Administration of $20 \mu \mathrm{M}$ RACC exhibited an inhibitory effect on MG-63 tumour growth, based on the reduction in tumour wet weight (67\% reduction, Fig. $8 \mathrm{a}$ ). We used $\mathrm{HABP}$ staining to analyse the HA retention in the local tumour inhibited by RACC treatment. The results revealed a significantly lower HA retention in RACCtreated local tumours compared to that in the control tumours (Fig. 8c-e). RACC treatment resulted in a significant $(84 \%)$ reduction in the number of metastatic lesions which was visually analysed (Fig. 8b). RACC-treated mice showed significantly lower number of metastases compared to that in the control mice.

\section{Discussion}

In the present study, RACC-incorporated GC nanoparticles formed by electrostatic interaction between $-\mathrm{COOH}$ group of RACC and $-\mathrm{NH}_{2}$ group of glycol chitosan were prepared. The presence of reactive $-\mathrm{NH}_{2}$ group makes chitosan a suitable substrate for drug conjugation and ion complex formation with anionic drugs [14, 34-36]. Thünemann and Beyermann initially developed the concept of nanoparticle formation acid and positively charged macromolecules $[29,30]$. Since then nanoparticle targeted treatment of cancer has been studied extensively [31-33].

Taking into consideration poor bioavailability of RACC, we transfected RACC-incorporated GC nanoparticles into 


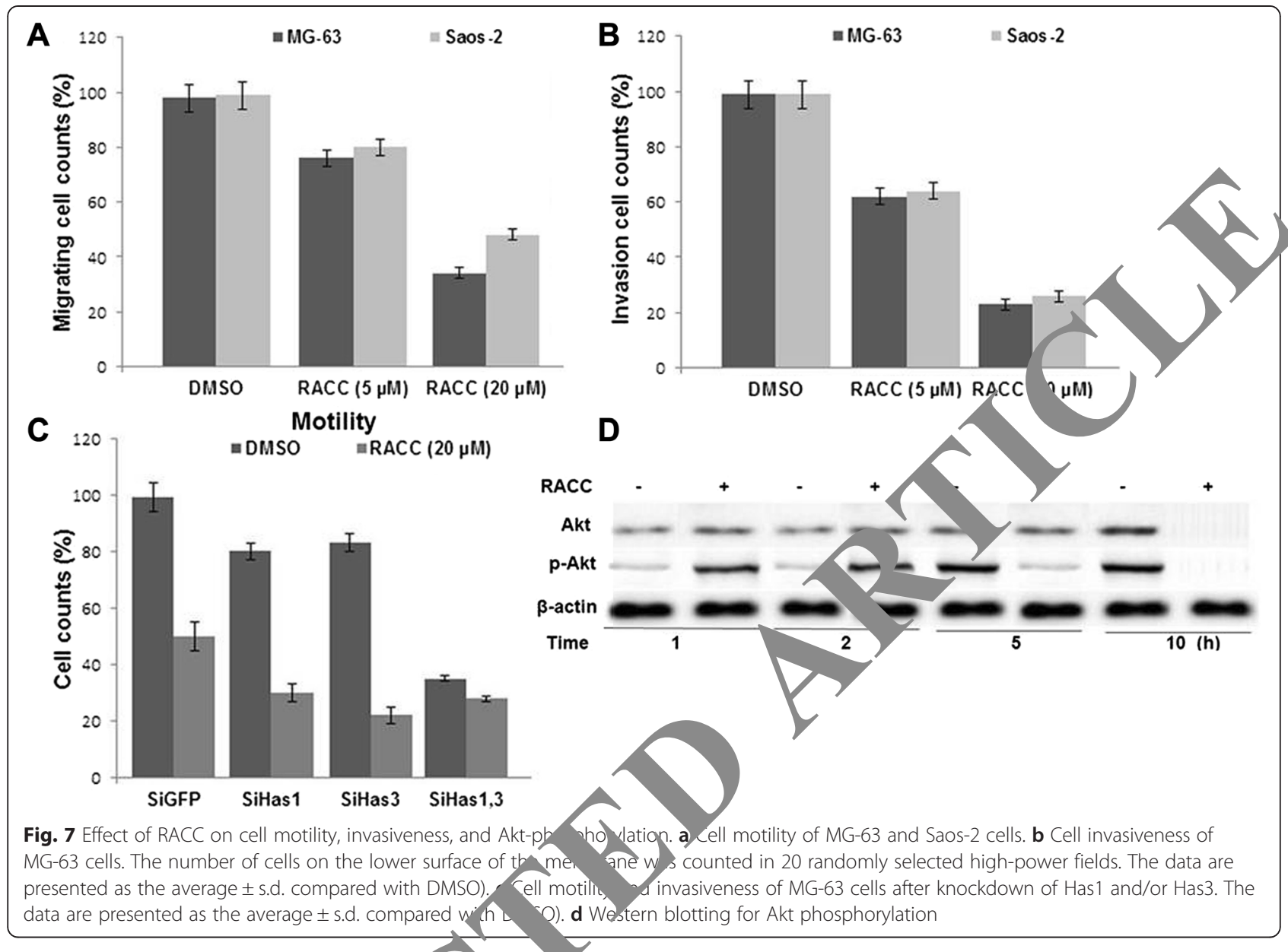

human osteosarcoma cells to investig te its effect on cell proliferation and cell cycle. There wa ionificant inhibition in cell proliferation on satment with RACCincorporated GC nanoparticles a/ concentration of $20 \mu \mathrm{M}$ of RACC within 2 . The proliferation inhibition continued for $72 \mathrm{~h}$ th offec was seen to be maximum on day 4. Farther restigation revealed that RACC transfection in -63 an Saos-2 human osteosarcoma cells caused inhibil of Ezh2 expression. The inhibition was seen after $24 \mathrm{~h}$ o $\mathrm{RACC}$ transfection at $20 \mu \mathrm{M}\left(\mathrm{IC}_{50}\right.$ value) cu rut on and lasted for $72 \mathrm{~h}$. The results from ap $r$ sis a $\mathrm{n}$-crosis assay showed increase in the peranta of ayoptosis on increasing the concentration of $\mathrm{R}$. C. Our results from flow-cytometry demonstrate that osteo Coma cells undergo apoptosis through mitochondrial pathway. The Bax and Bcl-2 proteins were seen to translocate from mitochondria into cytoplasm where they led to release of cytochrome c. Cytochrome c then activates caspase 9 and caspase 3, which play key roles in the apoptosis pathway [37]. The increase in concentration of RACC in RACC-incorporated GC nanoparticle from $5 \mu \mathrm{M}$ to $20 \mu \mathrm{M}$ significantly reduced the mitochondrial membrane potential in MG-63 cells. Therefore, these results suggest that the RACC inhibition of Ezh2 expression induces apoptosis through the mitochondrial pathway in human osteosarcoma cells. Our results from flow cytometry also suggest that RACC induces cell cycle arrest in G0/G1 phase. Treatment of MG-63 and Saos-2 cells with $10 \mu \mathrm{M}$ concentration of RACC, led to an increase in the percentage of cells in G0/G1 phase with the subsequent decrease in $S$ and G2/M phase. The increase in concentration of RACC from $5 \mu \mathrm{M}$ to $20 \mu \mathrm{M}$ significantly increased the percentage of cells in G0/G1 phase.

The results from our study revealed that RACC exerted a multistep inhibitory effect on the tumourigenicity of osteosarcoma cells through inhibition of HA synthesis. HA being the major component of ECM, the reduction of Has subsequently causes the suppression of ECM production, particularly that of the cell-associated matrix. It is reported that cell-associated matrix is linked to tumourigenicity [38-40]. Our results demonstrate that the inhibition of cell-associated matrix formation through suppression of HA synthesis by RACC effectively suppressed the tumourigenicity. Thus, the anti-tumour activity of RACC may be partly through the depletion of cell-associated matrix formation. 

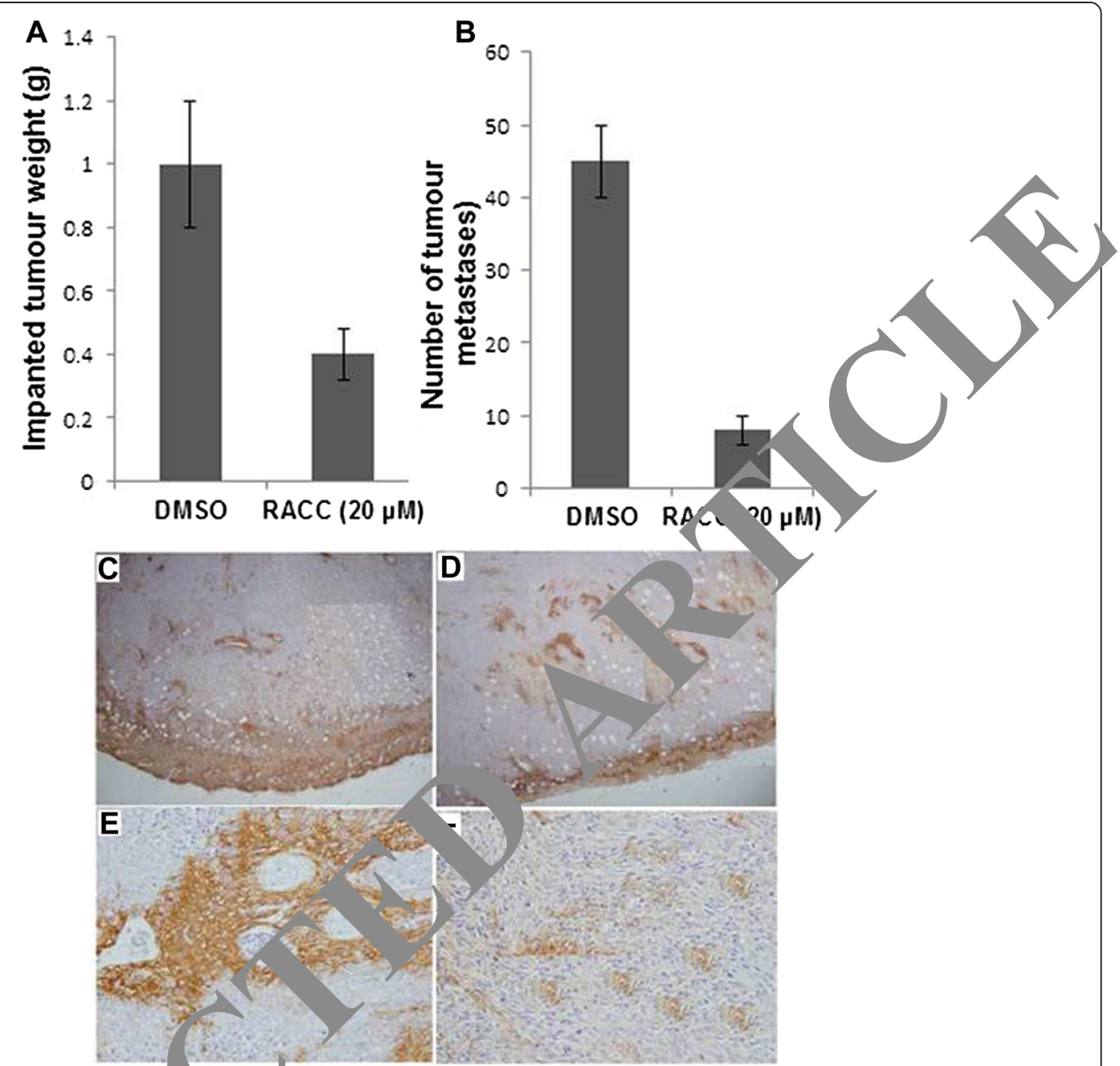

Fig. 8 Effect of RACC on implanted tumour $m$ and teosarcoma metastasis of MG-63 cells. a The wet weights of the transplanted tumour were measured. (b) The numbers of os nsarcoma mr rastases. Representative sections of transplanted tumours with HABP staining (c and $\mathbf{e}$; Control, $\mathbf{d}$ and $\mathbf{f}$; RACC treatment)

Recent studies hay so the the PI3K/Akt signalling pathway is si mifica " $\mathrm{v}$ involved in HA-induced cell motility and ineness. We also demonstrated that RACC-induced do regulation of Akt phosphorylation in osteos argoma cells Considering the delayed inhibition of Akt ${ }_{0}$ ho ylation (after $6 \mathrm{~h}$ ) by RACC in this stu RAc may indirectly affect Akt phosphorylation, ossil $v$ via suppression of HA synthesis, perturbation O. A-rcueptor interaction, or alteration of cell signalling Hways including Akt phosphorylation.

The degree of the inhibitory effects of RACC on the formation of osteosarcoma metastasis in vivo was markedly higher than that on the growth of the implanted primary tumour. In contrast to the growth of the primary tumour, multistep processes are associated with distant metastasis. In this study, RACC suppressed proliferation, motility, and invasion of osteosarcoma cells in vitro. Inhibition of these steps by RACC led to substantial suppression of tumour metastasis. Another explanation is that RACC affects the microenvironment of the primary and target organs. The tumour stroma and surrounding normal cells (immune cells, inflammatory cells, pericytes, vascular endothelial cells, and fibroblasts) can be affected by RACC, possibly via suppression of HA synthesis. Notably, in the current study, HA deposits were markedly suppressed not only in the periphery of the tumour, but also in the surrounding stromal tissues and perivascular region in vivo. In the clinical context, the strong suppressive effects of RACC on lung metastasis might be especially beneficial for patients with osteosarcoma, considering that the primary cause of death in this group is metastasis [41].

\section{Conclusions}

The present study demonstrates that RACC inhibits various processes of tumourigenicity in vitro in murine 
and human osteosarcoma cell lines, and markedly suppressed osteosarcoma metastasis. Thus RACCincorporated GC nanoparticles may be a promising strategy for the treatment of osteosarcoma.

\section{Materials and methods Cell culture}

Human osteosarcoma cell lines, MG-63 and Saos-2 were purchased from the Health Science Research Resources Bank (Osaka, Japan). The cells were maintained in RPMI 1640 medium (RPMI:ECM $=4: 1$ ) supplemented with $10 \%$ fetal bovine serum at $37{ }^{\circ} \mathrm{C}$ in $5 \% \mathrm{CO}_{2}$ in a humidified atmosphere.

\section{Chemicals and reagents}

Glycol chitosan (GC), retinoic acid chlorochalcone (RACC), dialysis membranes ( $\mathrm{MWCO}=12,000 \mathrm{~g} / \mathrm{mol}$ ) and propidium iodide (PI) were purchased from Sigma Chem. Co. Ltd. (St. Louis, MO, USA). FITC-annexin V was obtained from Santa Cruz, CA, 95060, USA.

\section{Ethical statement}

The present study was approved by the Institutional Review Board and Ethics Committee of the Nanjing University, Jiangsu, China.

\section{Preparation of RA-incorporated GC nanoparticles} The RACC-incorporated GC nanoparticles vere pared by adding a solution containing $5, \mathrm{n}_{\mathrm{o}}$, $\mathrm{ACC}$ is, $1 \mathrm{~mL}$ of DMF to an aqueous solution containit. $40 \mathrm{mg}$ of $\mathrm{GC}$ in $10 \mathrm{~mL}$ of deionized water while stirrins. The stirring was continued for $20 \mathrm{~min} u$ der darkened conditions. A dialysis membrane (MW $=12,000 \mathrm{~g} / \mathrm{mol}$, Sigma Chem. Co. Ltd. St. Loui MO, USA) was used to prepare dialyzed solution agains d $/ 4$ Led water by dialysis for 1 day. Out of $20 \mathrm{~L}$ prepared by adding deionized water to the di r ed lution, $100 \mu \mathrm{L}$ was diluted with $9.9 \mathrm{~mL}$ of D NDO. spectrophotometer (UV-1200, Shimadzu Co 4 Kyoto, Japan) was used to measure drug contents at $\mathrm{nm}$ and empty $\mathrm{GC}$ vehicles were used as a blank test. )

\section{Pro'”ratio. hioition assay (MTT assay)}

ea h wel of a 96-well plate, aliquots containing 2. 10 cells were seeded. The cells were incubated over oft in a $5 \% \mathrm{CO}_{2}$ incubator at $37{ }^{\circ} \mathrm{C}$ and then RACC-incorporated GC nanoparticle solution was added to each well. After dilution with RIMI 1640 (10 \% FBS), these were used to treat the tumor cells. RIMI 1640 (10\% FBS) with $0.1 \%$ (v/v) DMSO was used as control. The incubation for $48 \mathrm{~h}$ was followed by addition of $25 \mu \mathrm{L}$ of MTT ( $3 \mathrm{mg} / \mathrm{mL}$ in PBS) to each well and incubation was continued for $4 \mathrm{~h}$ more. To each well was added $100 \mu \mathrm{L}$ of SDS- $\mathrm{HCl}$ solution (SDS
$10 \% \mathrm{w} / \mathrm{v}, 0.01 \mathrm{M} \mathrm{HCl}$ ) and incubated again for $12 \mathrm{~h}$. An Infinite M200 pro reader (Tecan Austria GmbH, Salzburg, Austria) was used to measure the absorbance at $570 \mathrm{~nm}$. The viable cells were expressed as percentage of control and all the experiments were conducted in triplicate.

\section{Western blotting}

The transfected osteosarcoma cells from were $w_{\text {c }}$ d twice in PBS followed by addition Lysis buffer (50 mM Tris- $\mathrm{HCl} \mathrm{pH} \mathrm{7.4,} 137 \mathrm{mM} / \mathrm{NaCl}$, \& ofycerol, $100 \mathrm{mM}$ sodium vanadate, $1 \mathrm{mM}$ SMSF, $10 \mathrm{~m}$. $/ \mathrm{ml}$ aprotinin, $10 \mathrm{mg} / \mathrm{ml}$ leupeptin, $1 \% \mathrm{~N} \quad 40$, and $5 \mathrm{mM}$ cocktail). Bicinchoninic acid assa, BC/, nethod was used to determine protein cncentra $n$, Equal amounts of protein were loaded na solved by electrophoresis on a $10 \%$ polyacrylamide ge. The semi-dry method was used to transfer pro ins onto a PVDF membrane which was then block \% non-fat dry milk overnight. After TBST wash membrane was incubated for $2 \mathrm{~h}$ with prin antibodies and then washed again with TBST before in -ubation with secondary antibodies for $2 \mathrm{~h}$. Then $\mathrm{X}$-ray autoradiography was performed and the gra, cale images were analysed.

\section{v cytometric analysis}

Identification of apoptosis and necrosis in osteosarcoma cells was performed by propidium iodide and FITCannexin $\mathrm{V}$ reagents respectively. Treatment of cells with various concentrations of RACC-incorporated GC nanoparticles for $24 \mathrm{~h}$ was followed by washing with PBS. After suspension in binding buffer (10 mM HEPES $\mathrm{pH} 7.4,150 \mathrm{mM} \mathrm{NaCl}, 5 \mathrm{mM} \mathrm{KCl}, 1 \mathrm{mM} \mathrm{MgCl}_{2}$, and $\left.1.8 \mathrm{mM} \mathrm{CaCl}_{2}\right)$ containing FITC annexin $\mathrm{V}(1 \mu \mathrm{g} / \mathrm{mL})$ the pellets were incubated for 20 minutes. Then PI $(10 \mu \mathrm{g} / \mathrm{mL})$ was added to stain necrotic cells under dark conditions and incubation was continued for 10 minutes more. FAC Scan flow cytometer (Becton Dickenson Biosciences, San Jose, CA, USA) was used to analyse the cells immediately.

\section{Detection of Single-Strand DNA (ssDNA)}

In a 96-multiwell plate, 10000 cells/well were seeded and incubated with the RACC-incorporated GC nanoparticles. The cells were then fixed with $80 \%$ methanol for 30 minutes. The plates were dried and incubated with formaldehyde for $10 \mathrm{~min}$ at room temperature followed by $10 \mathrm{~min}$ at $75{ }^{\circ} \mathrm{C}$, and then at $4{ }^{\circ} \mathrm{C}$ for $5 \mathrm{~min}$. With $3 \%$ non-fat dry milk cells were incubated for $1 \mathrm{~h}$ followed by incubation with the antibody mixture (containing a primary monoclonal antibody to ssDNA and horseradish peroxidase-labeled secondary antibody) for $30 \mathrm{~min}$. The addition of 2-2'-azino-bis[3-ethylbenziazoline-6-sulfonic acid] solution permitted the reading of 
the plates at $405 \mathrm{~nm}$ in a standard microtiter reader. As positive control ssDNA and as negative control necrotic cells obtained by hyperthermia were used.

\section{Immunocytochemistry for Has}

Onto the chamber slides (BD Biosciences, Mountain View, CA, USA) $2.5 \times 10^{6}$ MG-63 cells were seeded and allowed to stick to the bottom. The cells were then incubated with various concentrations of RACC for $24 \mathrm{~h}$ and subjected to Has1 and Has3 immunocytochemistry. The antibodies against Has1 and Has3 were raised in rabbits by subcutaneous injection of the synthetic peptides.

\section{Motility and matrigel invasion assays}

Transwell motility chambers were used to analyse cell migration and invasion. For this, the 8 - $\mathrm{mm}$ pore diameter transwell motility chambers (Corning) were coated with matrigel (BD Biosciences) on undesurfaces. Into the upper chamber, $2 \times 10^{6}$ cells were plated in serum-free culture medium and the lower chamber was filled with medium containing $10 \%$ FBS. The plates were incubated for 24 hours at $37^{\circ} \mathrm{C}$. After incubation the upper surface of the compartment was cleaned. The inserts after methanol fixing were stained with crystal violet solution $(0.5 \%)$ followed by microscopic examination. The 5 areas were randomly selected and the cells were carculated. Experiments were performed in triplicates.

\section{Effects of RACC in vivo}

The dorsal flank of 5-week-old $\mathrm{C} 3 \mathrm{H} / \mathrm{He}$ male $\mathrm{n}$ were transfected with MG-63 cells $\left(2.5 \times 10^{6}\right)$ suspen ${ }^{2}$ ed in $200 \mathrm{ml}$ of serum-free DMEM. After 14 days of in vivo growth small tumours $(0.6-1.2 \mathrm{~cm}$ in met $)$ were observed. The mice were then ra mly assigned into two groups with 10 each. The mice in $C$ group received 15 mg RACC with $100 \%$ f $0.4 \%$ CMC solution intraperitoneally daily weas tho nice in control group were given sam amo to $0.4 \% \mathrm{CMC}$ solution. Twenty days a the tre, ument, the mice were sacrificed, and their tu. urs were excised and analysed for tumour wet weight ond number of metastatic colonies. All anin - apel ments were performed in accordance wit the tional Cancer Research Institute (2010) uide nes for the welfare and use of animals in cancer ro rcir and under approval of the institutional animal ethic ommittee.

\section{HA staining for cells and tissues}

The hyaluronic acid binding protein (HABP; Seikagaku, Tokyo, Japan) was used to examine the accumulation of hyaluronan in cells and in vivo tissues with or without RACC. MG-63 cells were distributed onto chamber slides (BD Biosciences) and allowed to adhere to the bottom. The cells were then incubated with various concentrations of RACC with or without exogenous $200 \mathrm{mg} \mathrm{ml}^{-1}$ of $\mathrm{HA}$ for $72 \mathrm{~h}$. After HABP staining, the cells and local tumours were incubated with a $2.0 \mathrm{mg} \mathrm{ml}^{-1}$ biotinylated HABP probe for $1 \mathrm{~h}$ at room temperature. Streptavidin-peroxidase reagents (Nichirei, Tokyo, Japan) and diaminobenzidinecontaining substrate solution (Nichirei) were used to analyse b-HABP binding.

\section{HA quantification}

MG-63 cells were incubated with or hout $0 \mathrm{M}$ RACC for 6,12 , and $24 \mathrm{~h}$. The cels were h bated for $10 \mathrm{~min}$ at $37{ }^{\circ} \mathrm{C}$ with trypsin-E TA followed by PBS wash to remove the cell-s' rfac ssociated HA. The cells were then placed in $\mathrm{Pr}$ se 1 solution $(0.15 \mathrm{M}$ Tris- $\mathrm{HCl}, \mathrm{pH} 7.5,0.1 \mathrm{M} \mathrm{Na} 10 \mathrm{mM} \mathrm{CaCl}_{2}$, and $5 \mathrm{mM}$ deferoxamin $\mathrm{m}$ late containing 20 units of protease $\mathrm{K}$ ) and in bated $2 \mathrm{~h}$ at $55^{\circ} \mathrm{C}$. For inactivation of the p tea. activity samples were heated at $100{ }^{\circ} \mathrm{C}$ for $20 \quad$ centrifuged at $12000 \mathrm{~g}$ for $45 \mathrm{~min}$ a $+4{ }^{\circ} \mathrm{C}$. Th apernatants were analysed for HA concentra wsing a sandwich enzyme-linked immunosorbent assay.

\section{Stat. cal analysis}

he i. vitro quantitative experiments were performed in $\operatorname{tr}_{1}$ cates, and analysis of variance followed by BonferroniJunn post-hoc test was used to assess differences between means. Student's t-test was used for statistical comparisons between the two groups.

\section{Abbreviations}

GC: Glycol chitosan; RACC: Retinoic acid chlorochalcone; OD: Optical density; Pl: Propidium iodide.

\section{Competing interests}

The authors declare that there is no conflict of interests regarding the publication of this paper.

\section{Authors' contributions}

The authors' responsibilities were as follows: YQ, LZ, CW, BZ \& QW conceived and designed this study, interpreted the data, and edited the manuscript. RY \& ZL participated in the statistical analysis of the data and edited the manuscript. All authors read and approved the final manuscript.

\section{Acknowledgments}

This work supported by the Jilin Provincial Science and Technology Department Program (No.20130206060GX /20150414006GH) and the Norman Bethune B Program of Jilin University (No. 2012216).

\section{Author details}

${ }^{1}$ Department of Orthopedics, The Second Hospital of Jilin University, Changchun, Jilin 130041, China. ${ }^{2}$ Nursing School, Changchun University of Chinese Medicine, Changchun, Jilin 130117, China. ${ }^{3}$ Norman Bethune Medical School, Jilin University, Changchun, Jilin 130021, China.

Received: 23 February 2015 Accepted: 26 June 2015 Published online: 14 July 2015

\section{References}

1. Meyers PA, Gorlick R. Osteosarcoma. Pediatr Clin North Am. 1997;44:973-89. 
2. Link MP, Eilber F. Pediatric oncology: Osteosarcoma. In: Pizzo PA, Poplack DG, editors. Principles and Practice of Pediatric Oncology. Philadelphia, PA: Lippincott; 1989

3. Bielack SS, Bernstein ML. Osteosarcoma. Cancer in Children: Clinical Management. 5 edition. New York, NY: Oxford University Press; 2005.

4. Mankin HJ, Mankin CJ, Simon MA. The hazards of the biopsy, revisited. Members of the Musculoskeletal Tumor Society. J Bone Joint Surg Am. 1996;78:656-63.

5. Enneking WF, Spanier SS, Goodman MA. A system for the surgical staging of musculoskeletal sarcoma. Clin Orthop. 1980;153:106-20.

6. Janeway K, Gorlick R, Bernstein M. Osteosarcoma. In: Orkin S, Fisher D, Look A, Lux S, Ginsburg D, Nathan D, eds. Oncology of Infancy and Childhood. Philadelphia: Saunders Elsevier 2009; 871-910

7. Marina N, Gebhardt M, Teot L, Gorlick R. Biology and therapeutic advances for pediatric osteosarcoma. Oncologist. 2004;9:422-41.

8. Gorlick R, Toretsky J, Marina N, et al. Bone tumors. In: Kufe D, Pollock R, Weichselbaum R, et al. eds. Cancer Medicine, 6th ed., Vol. 2. Hamilton, Ontario, Canada: BC Decker 2003; 2383-2406.

9. Marina N, Gorlick R, Bielack S. Pediatric osteosarcoma. In: Carroll W, Finlay J, editors. Cancer in Children and Adolecents, vol. 2010. Sudbury, MA: Jones and Bartlett; 2008. p. 383-94.

10. Chou AJ, Geller DS, Gorlick R. Therapy for osteosarcoma: where do we go from here? Paediatr Drugs. 2008;10:315-27.

11. O'Day K, Gorlick R. Novel therapeutic agents for osteosarcoma. Expert Rev Anticancer Ther. 2009;9:511-23.

12. Müller $S$, Hoege $C$, Pyrowolakis $G$, Jentsch S. SUMO, ubiquitin's mysterious cousin. Nat Rev Mol Cell Biol. 2001:2:202-10.

13. Geiss-Friedlander R, Melchior F. Concepts in sumoylation: a decade on. Nat Rev Mol Cell Biol. 2007:8:947-56.

14. Yeh ET. SUMOylation and De-SUMOylation: wrestling with life's processes. J Biol Chem. 2009;284:8223-7.

15. Kim JH, Baek SH. Emerging roles of desumoylating enzymes. Biochim Biophys Acta. 1792;2009:155-62.

16. Bailey D, O'Hare P. Characterization of the localization and proteolytic ar' of the SUMO-specific protease, SENP1. J Biol Chem. 2004;279:692-70?

17. Cheng J, Wang D, Wang Z, Yeh ET. SENP1 enhances androgen rcep dependent transcription through desumoylation of histone eacetylase Mol Cell Biol. 2004;24:6021-8.

18. Itahana Y, Yeh ET, Zhang Y. Nucleocytoplasmic shuttling modu and ubiquitination-dependent turnover of SUMO- pecitre protease $\mathrm{MO}$ Cell Biol. 2006;26:4675-89.

19. Zhang $\mathrm{H}$, Saitoh $\mathrm{H}$, Matunis MJ. Enzymes of the MO modif Lation pathway localize to filaments of the nuclear pore nolex lol Cell Biol. 2002;22:6498-508.

20. Orfanos CE, Ehlert R, Gollnick $H$. The reti naview of their clinical pharmacology and therapeutic use. Drug. 1/,8/,459-503.

21. Kligman AM. The growing in ne of trpical retinoids in clinical dermatology: A retrosper and rospectj ,e analysis. J Am Acad Dermatol. 1998;39:S2-7.

22. Chandraratna RA. arrent rese and future developments in retinoids: Oral and topica' as s. Cutis. 19, $, 61: 40-5$.

23. Zheng Y, Kram er PM, et RA, Steele VE, Kelloff GJ, Pereira MA. Effect of retinoids 1 NOM-induce cancer in rats: Modulation of cell proliferation, apopt is and aberrant Crypt foci. Carcinogenesis. 1999;20:255-60.

24. Liang, nava J Rao JN, Ordonez JV, Dawson Ml, Shroot B, et al. cunthetic oid CD437 induces S-phase arrest and apoptosis in human Pi ate canc cells LNCaP and PC-3. Prostate. 1999;38:228-36. W R R 2 RK, Knudsen ES, Williams JR, Dillehay LE, Nelkin BD, et al. stinorc acid-mediated growth inhibition of small cell lung cancer cells is a ated with reduced myc and increased p27Kip1 expression. Int J Caricer. 1999:80:935-43.

26. Mologni L, Ponzanelli I, Bresciani F, Sardiello G, Bergamaschi D, Gianni M, et al. The novel synthetic retinoid 6-[3-adamantyl-4-hydroxyphenyl]-2naphtalene carboxylic acid (CD437) causes apoptosis in acute promyelocytic leukemia cells through rapid activation of caspases. Blood. 1999;93:1045-61.

27. Irving H, Lovat PE, Hewson QC, Malcolm AJ, Pearson AD, Redfern CP. Retinoid induced differentiation of neuroblastoma: Comparison between LG69, an RXR-selective analogue and 9-cis retinoic acid. Eur J Cancer. 1998;34:111-7
28. Dirks PB, Patel K, Hubbard SL, Ackerley C, Hamel PA, Rutka JT. Retinoic acid and the cyclin dependent kinase inhibitors synergistically alter proliferation and morphology of U343 astrocytoma cells. Oncogene. 1997;15:2037-48.

29. Yung WK, Kyritsis AP, Gleason MJ, Levin VA. Treatment of recurrent malignant gliomas with high-dose 13-cis-retinoic acid. Clin Cancer Res. 1996;2:1931-5

30. Defer GL, Adle-Biassette H, Ricolfi ML, Authier FJ, Chomienne C, Degos L, et al. All-trans retinoic acid in relapsing malignant gliomas: Clinical and radiological stabilization associated with the appearance of intr tumbral calcifications. J Neurooncol. 1997;34:169-77.

31. Kaba SE, Kyritsis AP, Conrad C, Gleason MI, Newman R, Levin VA E The treatment of recurrent cerebral gliomas with all-trans 'btinoic acid (tretinoin). J Neurooncol. 1997:34:145-51.

32. Saraswat B, Visen PK, Agarwal DP. Ursolic acid ic ted th Fucaly ptus tereticornis protects against ethanol toxicity $\mathrm{n}$ isolated rat atocytes. Phytother Res. 2000;14:163-6.

33. Stummer W, Kamp M. The importance of s ral resect on in malignant glioma. Curr Opin Neurol. 2009;22:\%

34. Holz-Smith SL, Sun IC, Jin L, Mat tews re $\mathrm{KH}$, Chen $\mathrm{CH}$. Role of human immunodeficiency virus (HIV vpe 1envelo int the anti-HIV activity of the betulinic acid derivative 950 timicrob) Agents Chemother. 2001:45:60-6.

35. Ma CM, Cai SQ, Cui lang RQ, Tu $\%$, Hattori M, et al. The cytotoxic activity of ursoli acid d ivatives, Eur. J Med Chem. 2005;40:582-9.

36. Li J, Guo WJ, Pan (ursolic acid and oleanolic acid on human colon carcinoma ce, HCT15, World J. Gastroenterol. 2002;8:493-5.

37. Hsu LY, PO, Lin Co oliferative inhibition, cell-cycle dysregulation and induction on by by bolic acid in human non-small cell lung cancer A549 cells. Life Sc1) 2004;75:2303-16.

38. Nishida $Y$, K pudson W, Knudson CB, Ishiguro N. Antisense inhibition of valuronan $y$ nthase-2 in human osteosarcoma cells inhibits hyaluronan tion and tumorigenicity. Exp Cell Res. 2005;307:194-203. Ho no K, Nishida Y, Knudson W, Knudson CB, Naruse T, Suzuki Y, et al. Hy luronan oligosaccharides inhibit tumorigenicity of osteosarcoma cell .hes MG-63 and LM-8 in vitro and in vivo via perturbation of hyaluronan-rich pericellular matrix of the cells. Am J Pathol. 2007;171:274-86.

40. Monz K, Maas Kuck K, Schumacher U, Schulz T, Hallmann R, Schnaker EM, et al. Inhibition of hyaluronan export attenuates cell migration and metastasis of human melanoma. J Cell Biochem. 2008;105:1260-6.

41. Ta HT, Dass CR, Choong PF, Dunstan DE. Osteosarcoma treatment: state of the art. Cancer Metastasis Rev. 2009;28:247-63.

\section{Submit your next manuscript to BioMed Central and take full advantage of:}

- Convenient online submission

- Thorough peer review

- No space constraints or color figure charges

- Immediate publication on acceptance

- Inclusion in PubMed, CAS, Scopus and Google Scholar

- Research which is freely available for redistribution 